\title{
Interpretation of Groundwater Flow into Fractured Aquifer
}

\author{
Sameh W. Al-Muqdadi, Broder J. Merkel \\ Geology Department, Technische Universität Bergakademie Freiberg, Freiberg, Germany \\ Email: sameh.wisam@web.de,merkel@geo.tu-freiberg.de
}

Received February 11, 2012; revised March 21, 2012; accepted April 16, 2012

\begin{abstract}
The region of investigation is part of the western desert of Iraq covering an area of about $12,400 \mathrm{~km}^{2}$, this region includes several large wadis discharging to the Euphrates River. Since the Tectonic features in particular fault zones play a significant role with respect to groundwater flow in hard rock terrains. The present research is focus on investigate lineaments that have been classified as suspected faults by means of remote sensing techniques and digital terrain evaluation in combination with interpolating groundwater heads and MLU pumping tests model in a fractured rock aquifer, Lineaments extraction approach is illustrated a fare matching with suspected faults, moreover these lineaments conducted an elevated permeability zone.
\end{abstract}

Keywords: Fault Interpretation; Lineaments Extraction; Remote Sensing; Digital Terrain Model; Analytical Pumping Test Evaluation

\section{Introduction}

Tectonic features and in particular faults, fault zones, and fracture zones play a significant role with respect to groundwater flow in hard rock terrains and show substantial impact at multiple scales. Faults and fracture zones may be areas of preferential flow but, may act as barriers as well. Whether a fault zone or fractures are water bearing or not is mainly controlled by the tectonic stress and strain and secondary fracture fillings. The permeability of fractures is assumed to be greater in the direction parallel to the principal stress field. Stress-relief fracturing might be as well a reason for increased permeability.

Numerous studies have been performed in order to determine fractured zones in aquifers and its impact onto groundwater flow and heads [1] examined the hydrogeology of regional flow system in carbonate terrain by large-scale pumping for irrigation. Water-level decline in corresponding wells was used as a proof to identify hydraulic connection between several wells. The study showed that the orientation of water bearing fractures or conduits inferred is consistent with the major orientation of local and regional structural features.

A conceptual model of groundwater flow was implemented by Mayo and Koontz, 2000 [2] for fractured zones associated with faulting in sedimentary rocks. The model is based on the results of field and laboratory investigations, groundwater and methane gas inflows from fault-fracture systems, showing that groundwater stored in fractured sandstone is confined above and below by clayey layers.

Electromagnetic surveys by VLF-WADI resistivity sounding was used by Sharma and Baranwal, 2005 [3] to interpret the geological structures and groundwater movement through fractures rock. Laboratory experiments were carried out by Qian et al., 2005 [4] to study groundwater flow in a single fracture with different surface roughness and apertures. Results show that the gradient of the Reynolds number versus the average velocity in a single fracture was almost independent of the change of fracture surface roughness, and it decreased when the aperture decreased under the same surface roughness.

Studying lineaments from remote sensed data is an alternative because high production areas in fractured aquifers are often associated with visible lineaments at the ground surface. An effective technique for delineation of fracture zones is based on lineament indices extracted from air-photos and from satellite imagery. In combination with structural and tectonic analysis information for understanding groundwater flow and occurrence in hardrock aquifers may be provided. Several techniques has been developed and applied to extract lineaments from air-photos, satellite images, and digital terrain models. A comprehensive toolkit was created by Raghavan et al., 1995 [5] for extracting lineaments from digital images using segment tracing and rotation transformation (START). This algorithm was coded in FORTRAN 77 
and implemented on a UNIX-based workstation and is executed in two stages: at first a binary line element image is generated using the segment tracing algorithm; then in a second step the rotation transformation algorithm is used to extract lineaments from the line element image. This algorithm may work with different data set such as LANDSAT MSS, LANDSAT thematic mapper (TM), DEM's as well as shaded aeromagnetic images.

Kim et al., 2004 [6] Developed for ArcView SHP files Avenue scripts to extract lineaments and lineament density from satellite images. The scripts may facilitate together with borehole date the analysis of the relationship between groundwater characteristics and lineament distribution. Accuracy of extracted lineaments depends strongly on the spatial resolution of images: the higher the resolution the better will be the quality of lineament map [7].

\section{Motivations}

The aim of this paper is to investigate lineaments that have been classified as suspected faults by means of remote sensing techniques and find out the impact of these lineaments into the groundwater flow.

\section{Regional Geological Setting}

The western desert of Iraq (south-west of Euphrates river) covers nearly $32 \%$ from the whole Iraq $\left(437.072 \mathrm{~km}^{2}\right)$ and habits a population of about 1.3 million [8], UNEP has adopted an index of aridity, defined as: $\mathrm{I}=\mathrm{P} / \mathrm{PET}$ where PET is the potential evapotranspiration and $\mathrm{P}$ is the average annual precipitation [9] Hype-arid: $<0.05$, arid: $0.05-0.2$, semi-arid: $0.2-0.5$, dry sub-humid: 0.5 0.65 . According to this definition the region has an Ivalue of 0.01 and is thus classifies as Hype-arid.

The rather flat terrain is sloping gently towards the Euphrates River. Rainfall is not sufficient to maintain a continuous plant cover. Ground water is found in several horizons in different depths. The majority of the ground water is nonrenewable flowing in confined aquifers. Recharge occurs locally by limited flood events only which happens immediately after rapid and intense rain events.

The region of investigation is part of the western desert of Iraq $\left(41.14^{\circ} \mathrm{E}-32.59^{\circ} \mathrm{N}\right.$ and $\left.42.78^{\circ} \mathrm{E}-31.86^{\circ} \mathrm{N}\right)$ covering an area of about $12,400 \mathrm{~km}^{2}$ including several large wadis, such as Ubaiydh, Amij, Ghadaf, Tubal, and Hauran discharging to the Euphrates River [10]. The region (Figure 1) was chosen for two reasons: on the one hand it was classified by Consortium-Yugoslavia, 1977 [11] as a promising groundwater abstraction zone and on the other hand offering a sufficient number of wells for carrying out a thorough ground water study. However, recent political events have made investigations in this area of Iraq rather difficult after 2008.

An elevation contour map was created by using the 90 $\mathrm{m}$ SRTM data. With respect to the ROI the highest value $(609 \mathrm{~m})$ is in the west while the lowest one $(233 \mathrm{~m})$ is in the east.

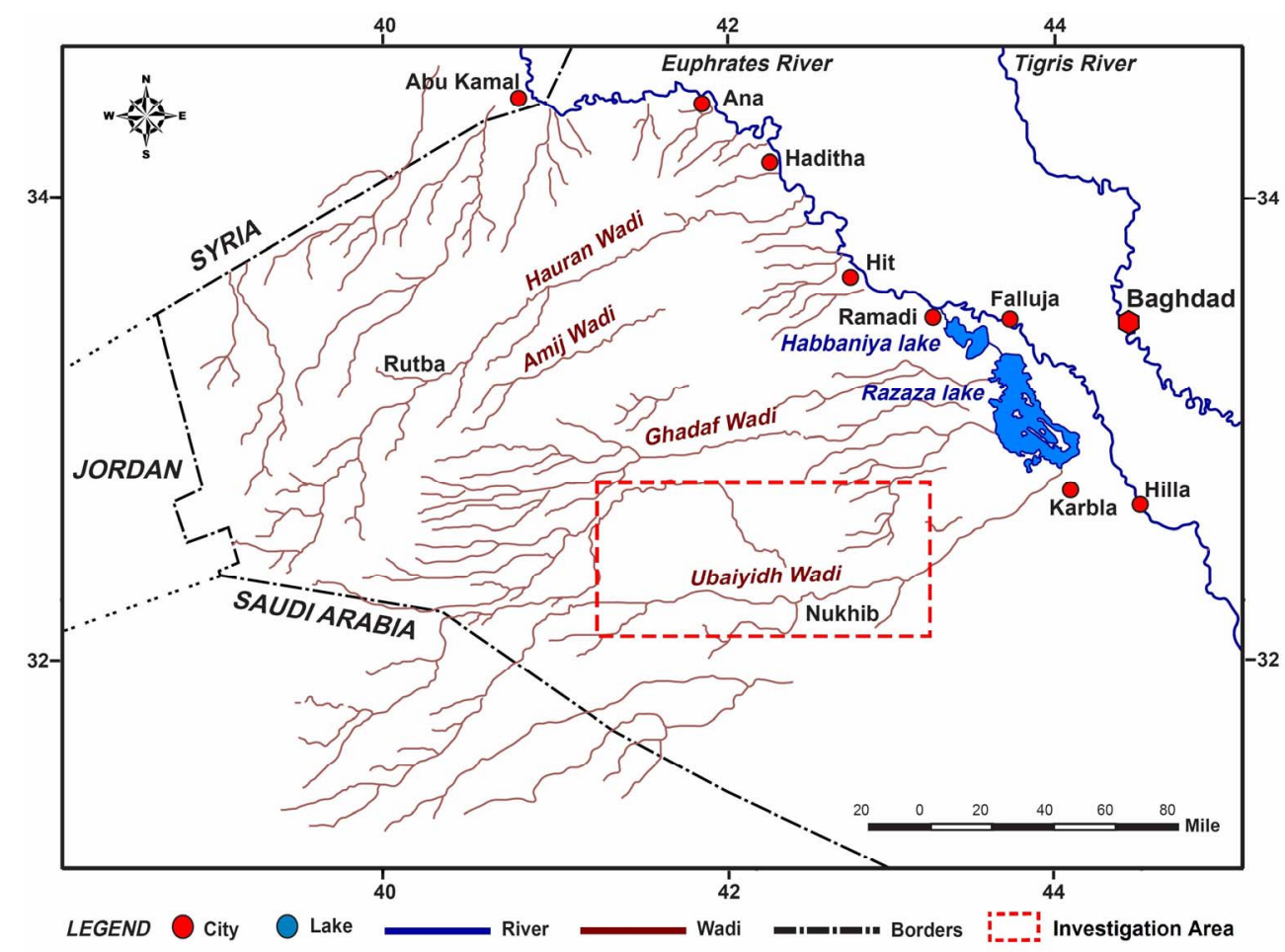

Figure 1. Western desert-Iraq. 
The region of interest is considered as a part from stable shelf zone/Rutba-Jazira sub zone [12]. The RutbaJazira zone is an inverted Paleozoic basin. The inversion started in the late Permian. Its basement was relatively stable during Mesozoic-Neogene time and more mobile during Infracambrian and Paleozoic times. The basement depth ranges from $5 \mathrm{~km}$ in Jazira area up to $11 \mathrm{~km}$ south of Rutba. Jazira area was part of the Rutba uplift domain in late Permian to early Cretaceous time, following the Cretaceous Jazira area subsided while Rutba remained uplifted these two areas are thus differentiated as separate sub zones.

Stratigraphic cross section for the Western Desert region has shown respectively the following formations Euphrates-L. Miocene, Dammam-M. Eocene, Umm ErRad-huma-M./U. Palaeocene, Tayarat-U. Cretaceous [13] where Limestone and dolomitic limestone are the most dominated units for these formations.

Based on (Buday, 1984) three local faults can be distinguished in the middle and eastern part of the ROI. The main directions for these faults are NS \& NE-SW; these directions are related to the Najd-Hejaz origin movement which belongs to the Precambrian-Palaeozoic [14].

Fault 1 has been described as a normal fault while faults 2 and 3 are classified as suspected faults. The Geological cross sections were generated by four boreholes
[11] (Figure 2): showing the main formation, faults and moreover a thin layer $\sim 20 \mathrm{~m}$. E recedes to $\sim 6 \mathrm{~m}$. W from marl located in between the two formations Umm ErRadhuma and Tayarat working as an aquiclude while lenses from marl are imbedded between Dammam and Umm Er-Radhuma formations. The general tectonic setting indicates that the maximum horizontal stress is orientated SW-NE.

Groundwater flow is suspected to be from $\mathrm{W}$ to $\mathrm{E}$ towards the Euphrates River with 102 pumping wells scattered in the area tapping the three main aquifers.

\section{Methodology}

A lineament is usually defined as a straight or curve linear feature to be seen on the ground surface. Lineaments can be manmade structures such as roads and canals or geological structures such as faults/fractures, folds, and unconformities, differences in vegetation and soil moisture, or drainage networks (rivers). Lineaments can be mapped during a field survey, or by using air photos and remote sensing data either manually or by means of pattern recognition algorithms [6]. On contrary lineaments can be traced from remote sensed data or digital terrain models by mathematical algorithms.

Sharpening tools are used for automatic merging a lowresolution color, multi-, or hyper-spectral image with a
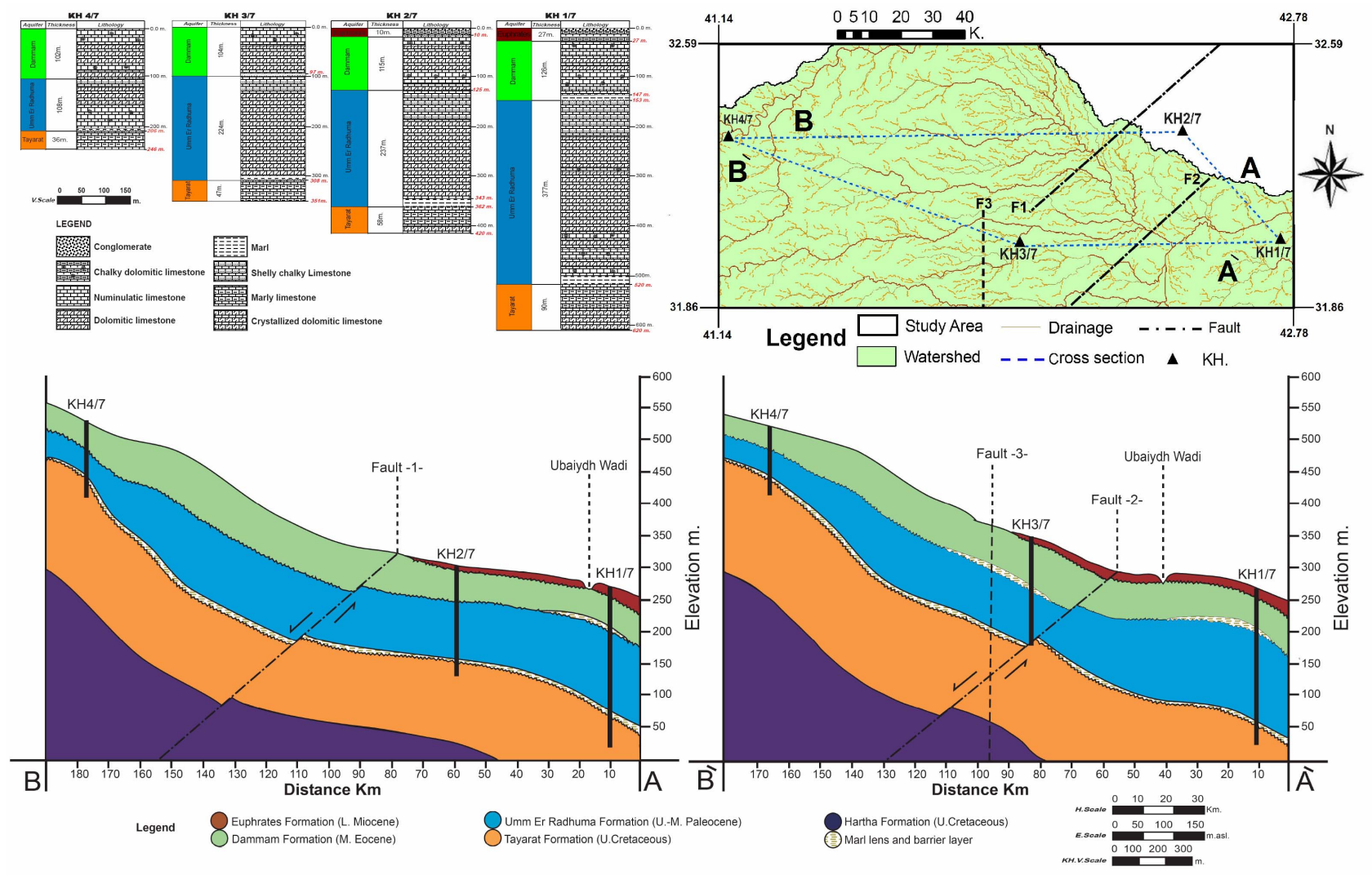

Figure 2. Cross sections. 
high-resolution grey scale image and resampling to the high-resolution pixel size. The Gram-Schmidt Spectral Sharpening algorithm [15] may sharpen multispectral data using high spatial resolution data and simulating a panchromatic image for the corresponding sensor ETM. Gram-Schmidt transformation is performed on the simulated panchromatic band and the spectral bands, using the simulated panchromatic as the first band by swapping the high spatial resolution panchromatic band with the first Gram-Schmidt band.

A directional algorithm implemented by ENVI is a first derivative edge enhancement filter that selectively enhances image features having specific direction components (gradients). The sum of the directional filter kernel elements is zero. The result is that areas with uniform pixel values are zeroed in the output image, while those that are variable are presented as bright edges.

The lineament extraction algorithm implemented by Geomatica is based on three fundamental steps to extract linear features from an image: at first an edge detection operator is used to produce a gradient image from the original image. Then a threshold value is applied on the gradient image to create a binary edge image and finally linear features are extracted from the binary edge image. The last step contains several sub steps such as edge thinning, curve pruning, recursive curve segmentation, and proximity curve linking.

If lineaments are faults and deep reaching fracture zones they may impact the groundwater flow either by being a zone of preferential flow or acting as barriers. Such zones can be recognized from groundwater contour lines for both unconfined and confined aquifers. Several spatial interpolation algorithms may be used for plotting groundwater contour lines.
Furthermore pumping test might provide additional information. A great variety of equations and procedures are known for pumping tests with observations wells. However, if as in the case of this study no observation wells are available the evaluation of such pumping test data is awkward. Analytical and numerical models may offer a viable approach. In this study the analytical model MLU was used for drawdown calculations and inverse modeling of transient well flow. MLU estimates selected aquifer parameters based on a best fit analytical solution to measured time-distance-drawdown data. The software includes an automatic curve-fitting algorithm computing optimized aquifer parameters and fitted drawdown results [16].

\section{Result and Discussion}

\subsection{Lineaments Interpretation}

SRTM data with $30 \mathrm{~m}$ resolution and $15 \mathrm{~m}$ Landsat ETM have been used to determine lineaments in the region of interest based on both extraction lineaments algorithm by Geomatics, 2001 [17] and directional filter algorithm by Haralick et al., 1987 [18]. Figure 3 shows that the lineaments F1 and F2 based on field survey [14] matching rather well with the automatically extracted lineaments with only a small difference between field data and remote sensed data. On contrary no evidence was found by lineament interpretation for the suspected F3 element.

\subsection{Groundwater Flow Direction}

Static water levels from 102 wells were used to determine the groundwater flow direction for these aquifers

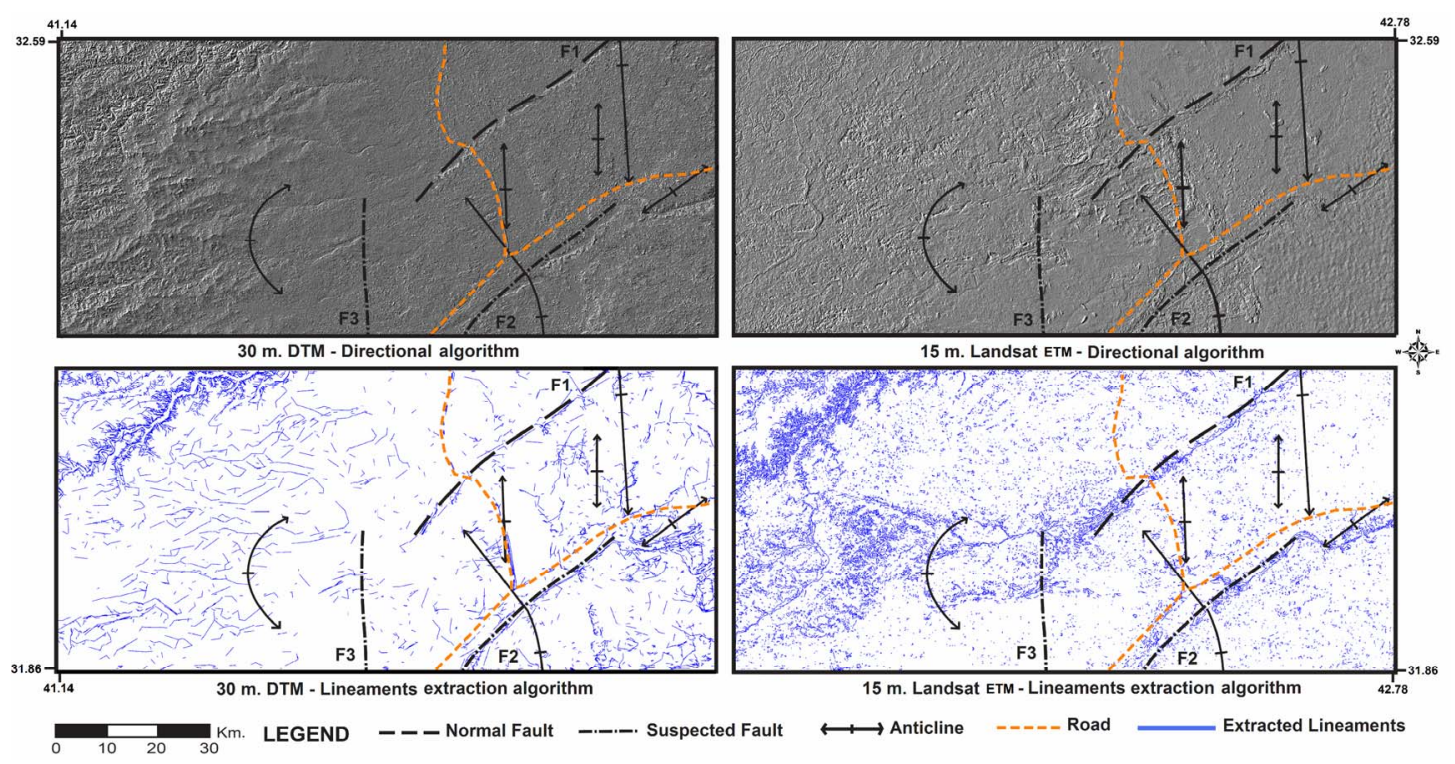

Figure 3. Extracted lineaments. 
by using different spatial interpolation algorithms. (Figure 4) shows the groundwater flow net for the three aquifers using minimum curvature algorithm [19]. Kriging [20] and radial basis function [21] did not result in significant different contour lines. The main flow direction is W-E with the highest value in the NW ( 487.5 masl./ well 5) while the lowest was in the NE ( 189.8 masl./ well 31).

Between the fault lines F1 and F2 the groundwater gradient is less steep than in the total area and the flow direction is diverted slightly from the general W-E direction to ESE. This can be explained by a better permeability in the area between F1 and F2. The main stress direction is $\sim 40^{\circ}$ and thus almost parallel to F1 and F2; perpendicular to this an anticline is assumed [14]. Thus it can be speculated that the entire area between F1 and F2 is showing a denser fracturing than the rest of the region of interest. Evidence for any impact on the groundwater hydraulics by the assumed F3 lineament was not found. Therefore the existence of this lineament F3 has to be negated.

\subsection{Pumping Test by Means of MLU Model}

Two pumping test were performed close to the lineament F2 in the unconfined aquifer Dammam using the wells 9 and 17, the location for both wells is shown in the groundwater flow net (Figure 4). Table 1 shows that there is a slight difference in depth to the groundwater between databank and field records. No adjustment of the pumping rate was possible and observation wells were
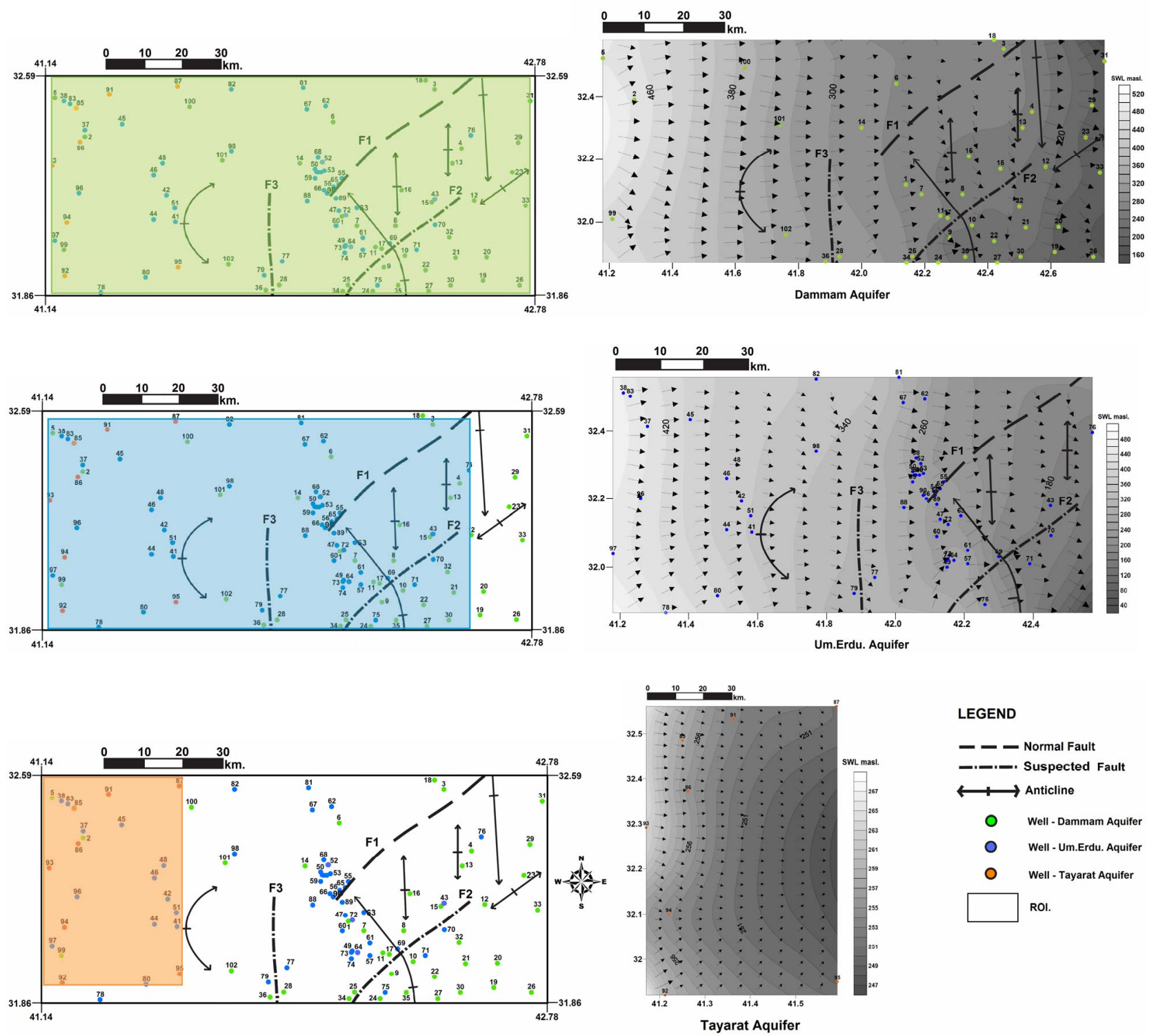

Figure 4. Groundwater flow net. 
not available. Pumping rate was determined by means of a stop watch filling a gradient container. Drawdown was monitored with a depth sounder in the pumping wells.

Pumping test in well no 9 was performed for 420 minutes to reach steady state, and then pump was switched off to monitor recovery reaching the former static level after 72 min (Table 2). Pumping test in well no 17 was performed for $360 \mathrm{~min}$ to reach steady state and then pump was switched off to monitor recovery which was reached after 300 minutes (Table 3). Results of pumping test and recovery evaluated with the analytical model MLU for Windows are presented in Figures 5 and $\mathbf{6}$, Results shown that well 17 has given a higher Transitivity value $0.1048 \mathrm{~m}^{2} / \mathrm{min}$ in compare with well 9 where $\mathrm{T}=0.0832 \mathrm{~m}^{2} / \mathrm{min}$, this results support the assumption of unique elevated permeability zone occurred in between of the F1 and F2 because of the tectonic stress and the anticline structure.

\section{Conclusion}

The lineaments F1 and F2 recognized by field survey could be confirmed by automated lineament extraction from $30 \mathrm{~m}$ SRTM data and $15 \mathrm{~m}$ Landsat ETM Interpolated groundwater heads of the uppermost Dammam aquifer display a different flow pattern between F1 and F2 which correlates with the assumption of an elevated permeability between these two lineaments due to tectonic stress and the anticline structure. Furthermore the results of the pumping tests support the hypothesis that the area between F1 and F2 is characterized by increased permeability.

\section{Acknowledgements}

The authors wish to acknowledge to University of Freiberg/Hydrogeology institute - Germany for providing the appropriate field instruments. A special thanks goes for

Table 1. Pumping test comparison wells.

\begin{tabular}{ccccccc}
\hline Well no. & Coordination & Elevation & Depth to the GW. Data Bank & Depth to the GW. Field & Difference & \% \\
\hline 9 & $42.28 / 31.95$ & 296.7 & 61.3 & 59.1 & 2.2 & 2 \\
17 & $42.32 / 32.09$ & 297.9 & 49.7 & 46.3 & 3.4 & 3.5 \\
& & & Average & & & $\mathbf{2 . 8}$ \\
\hline
\end{tabular}

Table 2. Recovery test data well 9. MLU aquifer test analysis—for unsteady-state flow.

\begin{tabular}{|c|c|c|c|c|c|}
\hline \multirow{2}{*}{ Observation well } & \multirow{2}{*}{ Aquifer } & \multirow{2}{*}{ Time (day) } & \multicolumn{3}{|c|}{ 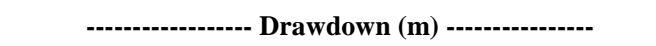 } \\
\hline & & & Calculated & Observed & Cal-Obs \\
\hline Observation well 9 & 1 & 0.29167 & 14.581 & 14.170 & 0.411 \\
\hline Observation well 9 & 1 & 0.29236 & 4.165 & 4.530 & -0.365 \\
\hline Observation well 9 & 1 & 0.29306 & 2.251 & 3.150 & -0.899 \\
\hline Observation well 9 & 1 & 0.29375 & 1.767 & 2.350 & -0.583 \\
\hline Observation well 9 & 1 & 0.29444 & 1.581 & 1.700 & -0.119 \\
\hline Observation well 9 & 1 & 0.29514 & 1.477 & 1.550 & -0.073 \\
\hline Observation well 9 & 1 & 0.29861 & 1.217 & 1.190 & 0.027 \\
\hline Observation well 9 & 1 & 0.30208 & 1.079 & 1.080 & -0.001 \\
\hline Observation well 9 & 1 & 0.30556 & 0.985 & 1.070 & -0.085 \\
\hline Observation well 9 & 1 & 0.31250 & 0.859 & 0.910 & -0.051 \\
\hline Observation well 9 & 1 & 0.32292 & 0.738 & 0.800 & -0.062 \\
\hline Observation well 9 & 1 & 0.33958 & 0.617 & 0.690 & -0.073 \\
\hline Observation well 9 & 1 & 0.34375 & 0.595 & 0.580 & 0.015 \\
\hline
\end{tabular}

Sum of squares: $1.4896 \mathrm{E}+00 \mathrm{~m}^{2} ; \mathrm{K}=0.00208 \mathrm{~m} / \mathrm{min} ; \mathrm{T}=0.0832 \mathrm{~m}^{2} / \mathrm{min}$. 
Table 3. Recovery test data well 17. MLU aquifer test analysis-for unsteady-state flow.

\begin{tabular}{|c|c|c|c|c|c|}
\hline \multirow{2}{*}{ Observation well } & \multirow{2}{*}{ Aquifer } & \multirow{2}{*}{ Time (day) } & \multicolumn{3}{|c|}{ 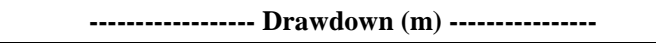 } \\
\hline & & & Calculated & Observed & Cal-Obs \\
\hline Observation well 17 & 1 & 0.25000 & 12.497 & 13.370 & -0.873 \\
\hline Observation well 17 & 1 & 0.25069 & 12.498 & 11.000 & 1.498 \\
\hline Observation well 17 & 1 & 0.25139 & 12.499 & 9.920 & 2.579 \\
\hline Observation well 17 & 1 & 0.25208 & 12.500 & 8.840 & 3.660 \\
\hline Observation well 17 & 1 & 0.25278 & 12.501 & 7.960 & 4.541 \\
\hline Observation well 17 & 1 & 0.25347 & 12.502 & 7.070 & 5.432 \\
\hline Observation well 17 & 1 & 0.26042 & 12.511 & 5.450 & 7.061 \\
\hline Observation well 17 & 1 & 0.27083 & 12.524 & 3.660 & 8.864 \\
\hline Observation well 17 & 1 & 0.28472 & 12.541 & 2.680 & 9.861 \\
\hline Observation well 17 & 1 & 0.30556 & 1.059 & 1.790 & -0.731 \\
\hline Observation well 17 & 1 & 0.33681 & 0.682 & 0.790 & -0.108 \\
\hline Observation well 17 & 1 & 0.37847 & 0.498 & 0.600 & -0.102 \\
\hline Observation well 17 & 1 & 0.43056 & 0.383 & 0.490 & -0.107 \\
\hline Observation well 17 & 1 & 0.49306 & 0.303 & 0.380 & -0.077 \\
\hline Observation well 17 & 1 & 0.57639 & 0.238 & 0.230 & 0.008 \\
\hline Observation well 17 & 1 & 0.70139 & 0.181 & 0.100 & 0.081 \\
\hline Observation well 17 & 1 & 0.86806 & 0.138 & 0.040 & 0.098 \\
\hline Observation well 17 & 1 & 1.07639 & 0.107 & 0.020 & 0.087 \\
\hline
\end{tabular}

Sum of squares: $2.9944 \mathrm{E}+02 \mathrm{~m}^{2} ; \mathrm{K}=0.00262 \mathrm{~m} / \mathrm{min} ; \mathrm{T}=0.1048 \mathrm{~m}^{2} / \mathrm{min}$.

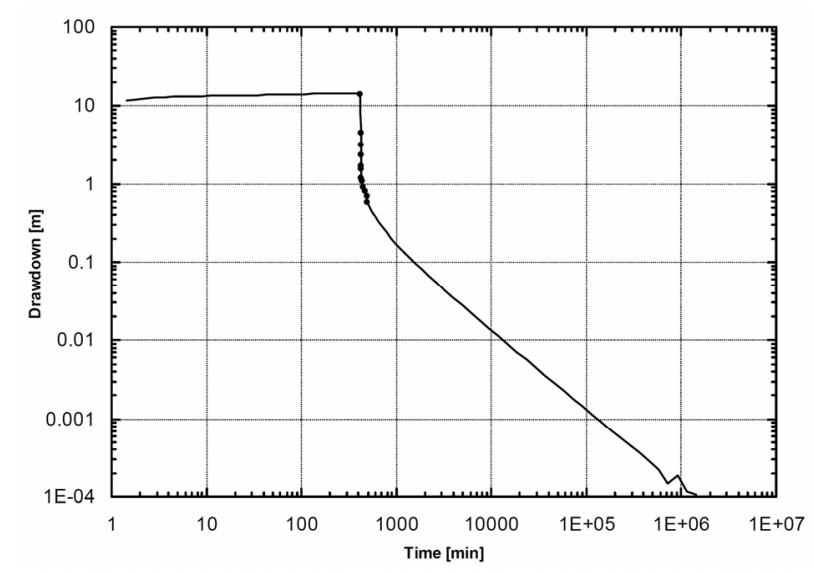

Figure 5. Recovery test well 9.

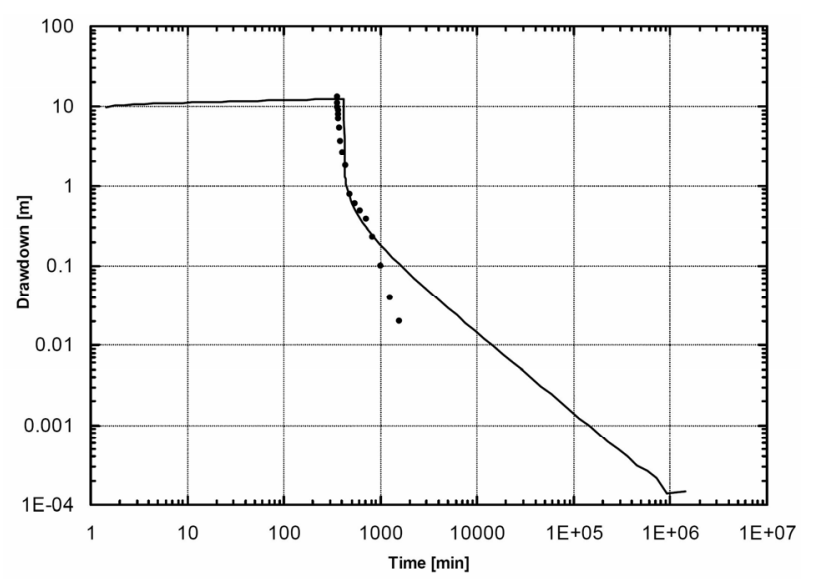

Figure 6. Recovery test well 17. logistic support during the fieldwork to the following colleagues (Khalid Hoshi, Amar Falah, Yasser Kassim and the guide Abo Duraid).

\section{REFERENCES}

[1] A. Braathen, "Kinematics of Post-Caledonian Polyphase Brittle Faulting in the Sunnfjord Region, Western Norway," Tectonophysics, Vol. 302, No. 1-2, 1999, pp. 99121. doi:10.1016/S0040-1951(98)00281-9

[2] A. L. Mayo and W. Koontz, "Fracture Flow and Groundwater Compartmentalization in the Rollins Sandstone, Lower Mesaverde Group, Colorado, USA," Hydrogeology Journal, Vol. 8, No. 4, 2000, pp. 430-446. doi:10.1007/s100400000056

[3] S. P. Sharma and V. C. Baranwal, "Delineation of Groundwater-Bearing Fracture Zones in a Hard Rock Area Integrating Very Low Frequency Electromagnetic and Resistivity Data," Journal of Applied Geophysics, Vol. 57, No. 2, 2005, pp. 155-166. doi:10.1016/j.jappgeo.2004.10.003

[4] J. Qian, H. Zhan, W. Zhao and F. Sun, "Experimental Study of Turbulent Unconfined Groundwater Flow in a Single Fracture," Journal of Hydrology, Vol. 311, No. 1-4, 2005, pp. 134-142. doi:10.1016/i.jhydrol.2005.01.013

[5] V. Raghavan, S. Masumoto, K. Koike and S. Nagano, "Automatic Lineament Extraction from Digital Images Using a Segment Tracing and Rotation Transformation Approach," Computers \& Geosciences, Vol. 21, No. 4, 1995, pp. 555-591. doi:10.1016/0098-3004(94)00097-E

[6] G. B. Kim, J. Y. Lee and K. K. Lee, "Construction of Lineament Maps Related to Groundwater Occurrence with ArcView and Avenue ${ }^{\mathrm{TM}}$ Scripts," Computers and Geosciences, Vol. 30, No. 9-10, 2004, pp. 1117-1126. 
doi:10.1016/j.cageo.2004.09.002

[7] L. Q. Hung, O. Batelaan and F. De Smedt, "Lineament Extraction and Analysis, Comparison of LANDSAT ETM and ASTER Imagery," Case Study: Suoimuoi Tropical Karst Catchment, 2005, p. 59830T-1.

[8] NIC, "Republic of Iraq National Investment Commission," 2004.

[9] V. Unep, "World Atlas of Desertification," 1992.

[10] N. I. Division, "Western Desert of Iraq," University of Texas Libraries, Austin, 1944.

[11] Consortium-Yugoslavia, "Hydrogeological Explorations and Hydrotechnical Work-Western Desert of IRAQ. Blook7," Directorate of Western Desert Development Projects, Anbar Province, 1977.

[12] S. Z. Jassim, J. C. Goff and M. Muzeum v Brn, "The Geology of Iraq," Geological Society, 2008.

[13] T. Buday and J. Hak, "The Geological Survey of the Western Part of the Western Desert. No.1000," The State Company of Geological Survey and Mining, IRAQ, 1980.

[14] T. Buday and S. Z. Jassim, "Tectonic Map of IRAQ," Geosurv. Iraq., Baghdad, 1984.

[15] C. A. Laben and B. V. Brower, "Process for Enhancing the Spatial Resolution of Multispectral Imagery Using Pan-Sharpening," Google Patents, 2000.

[16] C. J. Hemker, "Transient Well Flow in Layered Aquifer Systems: The Uniform Well-Face Drawdown Solution," Journal of Hydrology, Vol. 225, No. 1-2, 1999, pp. 19-44. doi:10.1016/S0022-1694(99)00093-1

[17] P. C. I. Geomatics, “Geomatica Softwave Manual," 2001.

[18] R. M. Haralick, S. R. Sternberg and X. Zhuang, "Image Analysis Using Mathematical Morphology," IEEE Transactions on Pattern Analysis and Machine Intelligence, Vol. 9, No. 4, 1987, pp. 532-550. doi:10.1109/TPAMI.1987.4767941

[19] W. H. F. Smith and P. Wessel, "Gridding with Continuous Curvature Splines in Tension," Geophysics, Vol. 55, 1990, p. 293. doi:10.1190/1.1442837

[20] N. Cressie, "The Origins of Kriging," Mathematical Geology, Vol. 22, No. 3, 1990, pp. 239-252. doi:10.1007/BF00889887

[21] R. E. Carlson and T. A. Foley, "Interpolation of Track Data with Radial Basis Methods," Computers \& Mathematics with Applications, Vol. 24, No. 12, 1992, pp. 2734. doi:10.1016/0898-1221(92)90169-I 